\section{Oligocene mammals from Ethiopia and faunal exchange between Afro-Arabia and Eurasia}

\author{
John Kappelman ${ }^{1}$, D. Tab Rasmussen ${ }^{3}$, William J. Sanders ${ }^{4}$, \\ Mulugeta Feseha ${ }^{2}$, Thomas Bown ${ }^{5}$, Peter Copeland ${ }^{6}$, Jeff Crabaugh ${ }^{7}$, \\ John Fleagle ${ }^{8}$, Michelle Glantz ${ }^{9}$, Adam Gordon ${ }^{1}$, Bonnie Jacobs ${ }^{10}$, \\ Murat Maga ${ }^{1}$, Kathleen Muldoon ${ }^{3}$, Aaron Pan ${ }^{10}$, Lydia Pyne ${ }^{1}$, \\ Brian Richmond ${ }^{11}$, Timothy Ryan ${ }^{12}$, Erik R. Seiffert ${ }^{12}$, Sevket Sen ${ }^{13}$, \\ Lawrence Todd ${ }^{9}$, Michael C. Wiemann ${ }^{14}$ \& Alisa Winkler ${ }^{10,15}$
}

${ }^{1}$ Department of Anthropology, and ${ }^{2}$ Department of Geological Sciences, University of Texas, Austin, Texas 78712, USA

${ }^{3}$ Department of Anthropology, Washington University, St Louis, Missouri 63130, USA

${ }^{4}$ Museum of Paleontology, University of Michigan, Ann Arbor, Michigan 48109, USA

${ }^{5} 2300$ Arapahoe Avenue, no. 236, Boulder, Colorado 80302, USA

${ }^{6}$ Department of Geosciences, University of Houston, Houston, Texas, 77204-5503, USA

${ }^{7}$ Department of Geology and Geophysics, University of Wyoming, Laramie, Wyoming 82071-3006, USA

${ }^{8}$ Department of Anatomical Sciences, State University of New York, Stony Brook, New York 11794-8081, USA

${ }^{9}$ Department of Anthropology, Colorado State University, Fort Collins, Colorado 80523-1787, USA

${ }^{10}$ Department of Geological Sciences, Southern Methodist University, Dallas, Texas 75275-0395, USA

${ }^{11}$ Department of Anthropology, George Washington University, Washington DC 20052, USA

${ }^{12}$ Department of Biological Anthropology and Anatomy, Duke University, Durham, North Carolina 27708-0383, USA

${ }^{13}$ Museum National d'Histoire Naturelle, Laboratoire de Paléontologie,

8 rue Buffon, 75005 Paris, France

${ }^{14}$ Center for Wood Anatomy Research, USDA Forest Service, Forest Products Laboratory, One Gifford Pinchot Drive, Madison, Wisconsin 53705-2398, USA ${ }^{15}$ Department of Cell Biology, University of Texas Southwestern Medical Center, Dallas, Texas 75390, USA

Afro-Arabian mammalian communities underwent a marked transition near the Oligocene/Miocene boundary at approximately 24 million years (Myr) ago. Although it is well documented that the endemic paenungulate taxa were replaced by migrants from the Northern Hemisphere, the timing and evolutionary dynamics of this transition have long been a mystery because faunas from about 32 to $24 \mathrm{Myr}$ ago are largely unknown ${ }^{1}$. Here we report a late Oligocene fossil assemblage from Ethiopia, which constrains the migration to postdate 27 Myr ago, and yields new insight into the indigenous faunal dynamics that preceded this event. The fauna is composed of large paenungulate herbivores and reveals not only which earlier taxa persisted into the late Oligocene epoch but also demonstrates that one group, the Proboscidea, underwent a marked diversification. When Eurasian immigrants entered Afro-Arabia, a pattern of winners and losers among the endemics emerged: less diverse taxa such as arsinoitheres became extinct, moderately species-rich groups such as hyracoids continued into the Miocene with reduced diversity, whereas the proboscideans successfully carried their adaptive radiation out of Afro-Arabia and across the world.

The newly discovered fossils are from the Chilga region of Ethiopia's northwestern plateau at an elevation of about $1,950 \mathrm{~m}$ (Fig. 1). Sedimentary rocks total at least $130 \mathrm{~m}$ and are exposed in a series of stream and gully cuts ${ }^{2-5}$. The channel and floodplain deposits include reworked volcaniclastics, common but usually thin lignites ${ }^{2}$, and claystones and siltstones that often represent palaeosols with varying degrees of maturity. Fossils have been found in each of these settings. Earlier work with a rich pollen assemblage ${ }^{3}$ suggests that the sediments were deposited at an elevation of about $1,000 \mathrm{~m}$.

The sediments conformably overlie the uppermost Ethiopian plateau flood basalts. A basalt sample from the base of the section (Fig. 2) provides a whole-rock K-Ar date of $32.4 \pm 1.6 \mathrm{Myr}$ (see Supplementary Information) and offers a maximum age for the sediments. Duplicate ${ }^{40} \mathrm{Ar}-{ }^{39} \mathrm{Ar}$ analyses of $\mathrm{K}$-feldspar ${ }^{6}$ from a tuff within the fossiliferous portion of the sedimentary section yield ages with a weighted average of $27.36 \pm 0.11 \mathrm{Myr}$ (see Supplementary Information). These data, along with the results from palaeomagnetic studies ${ }^{7}$, support a correlation of the Chilga section with Chron C9n (ref. 8) (see Methods and Fig. 2). Our dates are consistent with new dates for the Ethiopian plateau flood basalts in both Ethiopia ${ }^{9-11}$ and Yemen ${ }^{12}$. Previous work ${ }^{3}$ reported that the Chilga sediments were no older than late Miocene in age, but the basalt that was dated by the whole-rock $\mathrm{K}-$ Ar technique at $8.0 \pm 1.2$ Myr is not conformable with the sediments.

There are now over 70 localities at Chilga with vertebrates, invertebrates, plant macrofossils and trace fossils (burrows, termiteria and rhizoliths). Vertebrate remains are usually fragmentary and represent medium- to large-sized herbivores. A possible preservational bias against small mammals may be due to diagenetic leaching of bone before fossilization. Vertebrates and plant macrofossils are often found together, with some leaf impressions preserved in clays that drape fossil vertebrates. Such occurrences are usually rare; the Chilga finds are significant in proving that these plants and animals were contemporaneous. Details of the macroflora will be provided elsewhere.

The Chilga mammals provide evidence for the continued evolution and diversification of some of the most common elements of the endemic Fayumian fauna (Table 1). One of the most distinctive taxa is a new species of Arsinoitherium (order Embrithopoda), well known for its distinctive horns and high-crowned molars. This new species (Fig. 3a-c) is the largest yet known of the genus. Arsinoitherium is best known from Palaeogene deposits of Egypt, Libya, Oman, and Angola ${ }^{13-17}$ and its occurrence at Chilga is the last

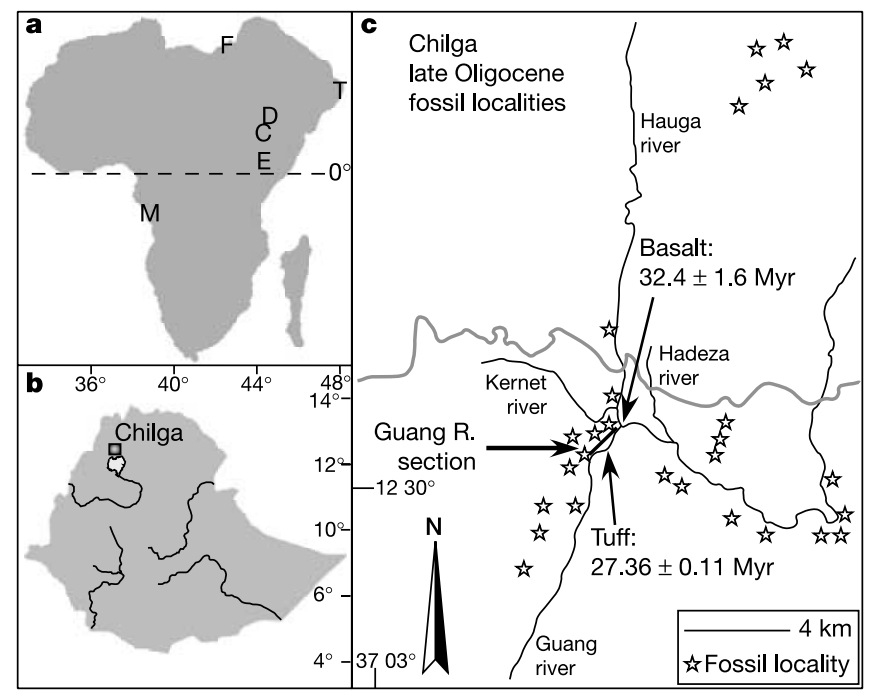

Figure 1 Map of Chilga and surrounding area containing the fossil localities. a, Map of Afro-Arabia with several important Palaeogene localities including Chilga (C; Ethiopia), Dogali (D; Eritrea) (ref. 27), Eragaleit (E; Kenya) (ref. 29), Fayum (F; Egypt) (ref. 13), Malembe (M; Angola) (ref. 16) and Thaytini and Taqah (T; Oman) (ref. 17). b, Location of Chilga in Ethiopia and north of lake Tana. c, Detailed map of the Chilga area showing the fossil localities, geological section (see Fig. 2) and dated rock samples (see Supplementary Information) along the Guang and Hauga rivers. 
known for the order Embrithopoda.

Hyracoids are moderately diverse at Chilga and document the continued presence of two well known but conservative Fayumian taxa. Pachyhyrax crassidentatus and Megalohyrax eocaenus are the most common large hyracoids from the early Oligocene ${ }^{18,19}$, with the latter first appearing in the late Eocene and changing little over its duration of several Myr. The new Chilga taxa are distinct from these at the specific level, with Pachyhyrax sp. nov. being smaller than $P$. crassidentatus and differing from it in its relatively higher, sharper and more delicate crests, whereas Megalohyrax sp. nov. (Fig. 3d) is remarkably close in size and structure to M. eocaenus but differs in premolar proportions. A third, larger hyracoid at Chilga is a new genus probably related to Pachyhyrax, whereas a fourth is closely related to Bunohyrax.

The Proboscidea has ancient Afro-Arabian roots ${ }^{20,21}$ and is the most diverse order of mammals at Chilga, represented by three families and five new species. Three of the Chilga proboscideans belong to the Palaeomastodontidae, a primitive family previously known from the late Eocene and early Oligocene of Afro-Arabia ${ }^{22}$. Two of these new species have close taxonomic ties to the genus Palaeomastodon, but are larger than the Fayum Palaeomastodon (Fig. 3e, f). The larger has some molar features that anticipate the morphology of the early Miocene mammutid Eozygodon (Fig. 3f). A

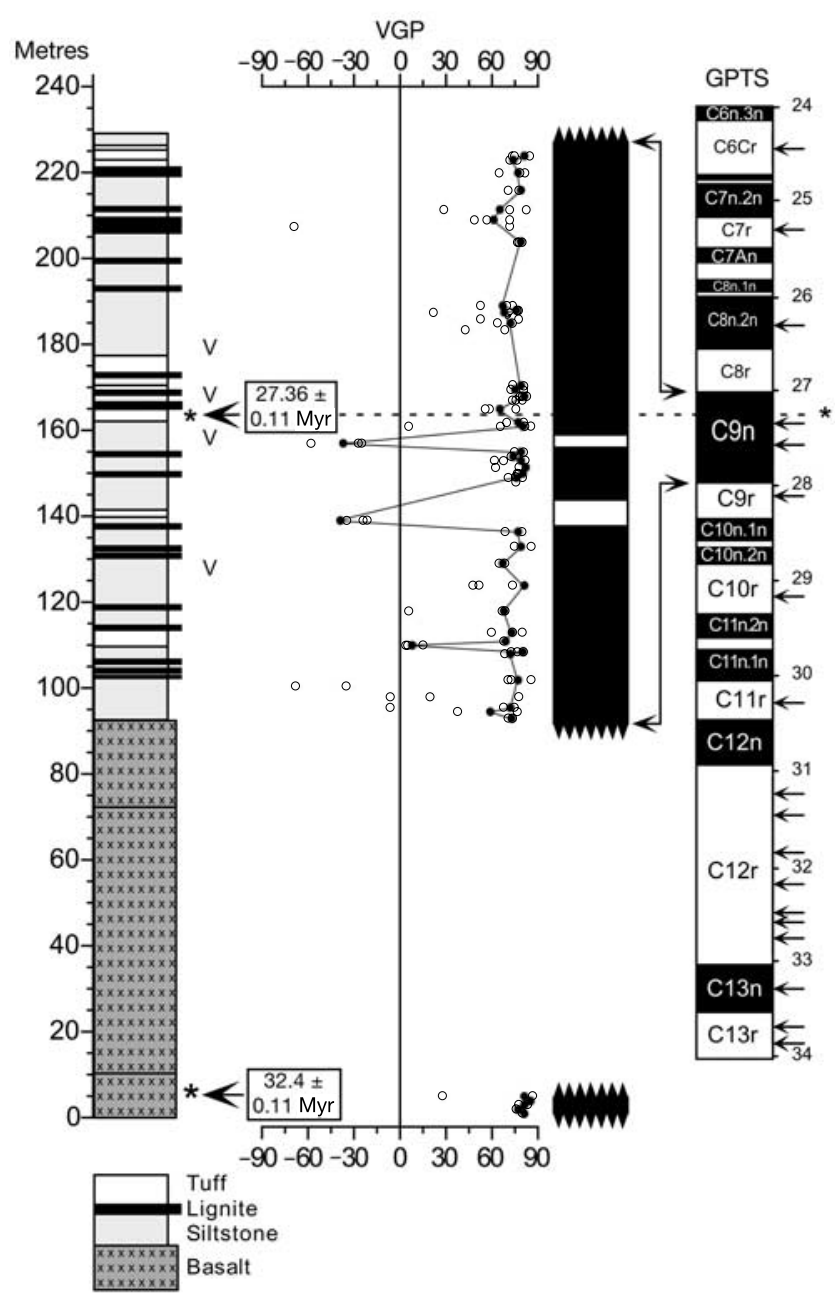

Figure 2 The Chilga section preserves volcanics and fluvial sediments. Vertebrate fossils date to around 27 Myr ago (see Methods for details). Ages along right of the GPTS panel are in Myr. V, vertebrate localities. VGP, virtual geomagnetic pole. White circles, samples; black circles, site means. Black bars, normal polarity; white bars, reversed polarity. Arrows, tiny wiggles. third new species (Fig. 3g) is closely aligned with the palaeomastodont Phiomia; its molars equal or exceed the uppermost size range of Fayum specimens of this genus and it has an outsized mandibular symphysis considerably longer than those of its Fayumian congenerics. The Chilga palaeomastodonts represent the youngestknown record for this family.

Chilga also documents the oldest occurrence of deinotheres (Fig. 3h, i). This distinctive family of proboscideans was previously known from the early Miocene through to the early Pleistocene epoch but its origins are poorly understood ${ }^{23}$. The new taxon clearly differs from other deinotheres, particularly in the nascent development of a third loph(id) in deciduous fourth premolars and first molars. The occlusal morphology of its cheek teeth suggests independent derivation from a bunolophodont form such as Moeritherium $^{23,24}$, rather than sharing an earlier ancestry with barytheres and numidotheres in the lophodont barytherioid group. The recovery of deinotheres at $27 \mathrm{Myr}$ ago extends the temporal range of this group by $7 \mathrm{Myr}$.

A third Chilga proboscidean family, Gomphotheriidae, is represented by a rare species with molars closely resembling those of primitive Gomphotherium (Fig. 3j), which previously had an earliest appearance of approximately 20-18 Myr ago in Africa and Eurasia $^{25-27}$. A similarly ancient but undescribed proboscidean with possible affinity to the Chilga gomphotheres is known from Dogali, Eritrea (Fig. 1a) ${ }^{28}$. The Chilga specimens are among the smallest to be attributed to Elephantoidea and markedly extend the known duration of this family back into the late Oligocene.

The recovery of these fossils from Ethiopia enlarges our understanding of some of the ecological attributes of Afro-Arabia's Oligocene fauna. For example, arsinoitheres, hyracoids, and palaeomastodonts are best known from Palaeogene sites in Egypt, Libya, Oman and Angola ${ }^{13-17}$ (Fig. 1), and the shared continental margin setting suggested that their habitat preferences were limited to coastal and estuarine environments. The discovery of these taxa in

\begin{tabular}{|c|c|c|c|}
\hline Taxonomic group & $\begin{array}{c}\text { Fayumian } \\
\text { Eocene/Oligocene }\end{array}$ & $\begin{array}{c}\text { Chilga } \\
\text { late Oligocene }\end{array}$ & $\begin{array}{c}\text { Rusingan } \\
\text { early Miocene }\end{array}$ \\
\hline
\end{tabular}

\section{Proboscidea}

Palaeomastodontidae

Palaeomastodon beadnelli

Palaeomastodon parvus

Palaeomastodon intermedius

aff. Palaeomastodon sp. nov. A

aff. Palaeomastodon sp. nov. B

Phiomia wintoni

Phiomia minor

Phiomia osborni

Phiomia sp. nov.

Gomphotheriidae

cf. Gomphotherium sp. nov.

Gomphotherium angustidens

Deinotheriidae

Gen. et sp. nov.

Prodeinotherium hobleyi

Hyracoidea

Saghatheriidae

Pachyhyrax crassidentatus

Pachyhyrax sp. nov.

Gen. et sp. nov., aff. Pachyhyrax

Megalohyrax eocaenus

Megalohyrax sp. nov.

Bunohyrax fajumensis

Bunohyrax major

Bunohyrax sp

Titanohyracinae

Embrithopoda

Arsinoitheriidae

Arsinoitherium zittel

Arsinoitherium sp. nov.

late Oligocene early Miocene

Taxonomic groups include order (in bold font), family/subfamily, genus and species. X, family or subfamily present; $x$, genus and species present; - , not present.

*Although this subfamily does not occur at Chilga, titanohyracines are known from either side of the transition but have much reduced diversity in the early Miocene. 
the highlands of northwestern Ethiopia instead suggests that they were widespread herbivores in Afro-Arabia, and occupied generalist niches with broad ecological tolerances. This observation is especially interesting in light of their overall low specific diversities.

Before the discovery of the Chilga fauna many aspects of AfroArabia's Oligocene/Miocene faunal transition were matters of speculation. It is now clear that the success of the invading northern immigrants was not a consequence of their movement into an ecological vacuum created by a much earlier extinction of the AfroArabian endemics; instead, the new fossils provide evidence that they evolved and diversified through the late Oligocene. Some taxa, such as arsinoitheres and hyracoids, continued a conservative evolutionary trajectory with size changes and slight morphological innovation, whereas others, such as the proboscideans, underwent a radiation that resulted in the origin of new families including the gomphotheres and deinotheres. At present, there is no indication
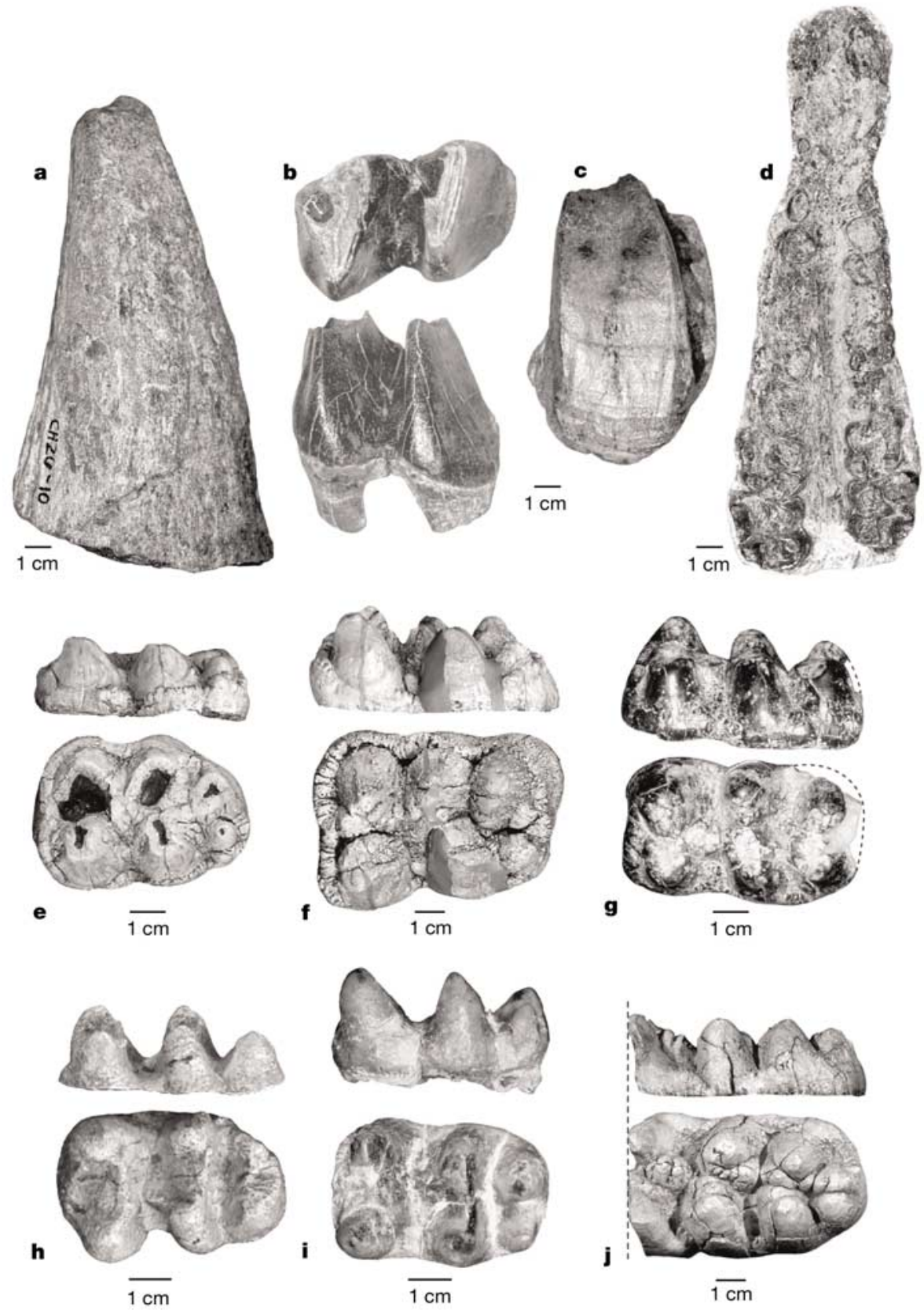

Figure 3 Fossils representing paenungulate taxa from Chilga. a, Specimen $\mathrm{CH} 26-10$ Arsinoitherium sp. nov., partial horn core (left side?), height $=225 \mathrm{~mm}$. b. Specimen CH25-17. Arsinoitherium sp. nov., lower molar, occlusal and buccal views. c, Specimen CH3-95. Arsinoitherium sp. nov., upper molar, distal view, height $=131 \mathrm{~mm}$. d, Specimen CH18-1. Megalohyrax sp. nov., palate, length $=210 \mathrm{~mm}$. e, Specimen CH35-23. New species, affinity to Palaeomastodon (aff. Palaeomastodon sp. nov. A), right third upper molar $\left(\mathrm{M}^{3}\right)$, buccal and occlusal views. Note the incomplete trilophodonty of the specimen. f, Specimen CH14-11. New species, affinity to Palaeomastodon (aff Palaeomastodon sp. nov. B), right $\mathrm{M}^{3}$, buccal and occlusal views. Note the incomplete trilophodonty of the specimen and its more rectangular occlusal outline in comparison with $\mathrm{CH} 35-23$. g. Specimen $\mathrm{CH}$ 9-1. Phiomia sp. nov., left M², lingual and occlusal views; portion of posterior end is missing (dotted line). $\mathbf{h}$, Specimen $\mathrm{CH} 35-3 c$. Deinotheriidae gen. et sp. nov., left first lower molar $\left(M_{1}\right)$, buccal and occlusal views. i, Specimen $\mathrm{CH} 35-3 \mathrm{a}$. Deinotheriidae gen. et sp. nov., right fourth lower deciduous premolar $\left(\mathrm{DP}_{4}\right)$, lingual and occlusal views. j, Specimen $\mathrm{CH}_{14-14}$. Cf. Gomphotherium sp. nov., right $\mathrm{M}_{3}$, lingual and occlusal views; anterior end is missing (dotted line). Note the rounded conelets, transverse continuity of half-lophids, larger posterior 'heel', and trefoil arrangement of outer main conelets and anterior and posterior accessory conules on the pretrite side. 
that contact with the invading migrants spurred on any of these changes; rather, fluctuations in environmental conditions possibly drove their continued evolution'. The discovery of new fossil localities dating to the Oligocene/Miocene boundary will be required to test the remaining possibility that competitive exclusion between the Afro-Arabian endemics and the invading immigrants was responsible for the extinction of the former. It seems likely that the phyletic conservatism and perhaps generalized habits of many of the endemic taxa greatly limited their ability to compete with the invaders; other endemics such as the proboscideans, which underwent greater diversification and specialization in the AfroArabian Oligocene, ended up on the winning side of the equation. $\square$

\section{Methods}

\section{Chronology}

The Chilga section has more than $90 \mathrm{~m}$ of volcanics at its base that are overlain by at leas $130 \mathrm{~m}$ of fluvial sediments. The basalt at the base of the section is dated at $32.4 \pm 1.6 \mathrm{My}$ (see Supplementary Information) and provides a maximum age for the section. Studies of the isothermal remanent magnetism ${ }^{7}$ for a suite of siltstones show a dominance of lowcoercivity grains indicating magnetite or maghaematite, an expected result given that basalts form the dominant parent material. All sediments show some evidence of intermediate-coercivity grains indicating specular haematite as well as small amounts of high-coercivity grains suggesting pigmentary haematite and goethite, but these are both minor constituents relative to the low-coercivity fraction. Stepwise alternating-field demagnetization was carried out on 118 samples with generally three samples per stratigraphic level. Palaeomagnetic reversal stratigraphy demonstrates a dominance of normal polarity. Duplicate ${ }^{40} \mathrm{Ar}-{ }^{39} \mathrm{Ar}$ age spectra analyses of $\mathrm{K}$-feldspar each separated from a tuff at $165 \mathrm{~m}$ produced a weighted average of $27.36 \pm 0.11 \mathrm{Myr}$ (see Supplementary Information) that provides an absolute tie point to Chron C9n (27.004-27.946 Myr). Small arrows to the far right of the geomagnetic polarity timescale (GPTS) ${ }^{8}$ in Fig. 2 represent "tiny wiggles" and the two brief reversals within Chron C9n may be present at Chilga, thereby providing additional but more indirect support for this correlation. Together these data suggest that this section is probably limited to the duration of Chron C9n ( $<1 \mathrm{Myr})$. Vertebrate localities occur primarily through the middle part of the section.

Received 8 May; accepted 30 September 2003; doi:10.1038/nature02102.

1. Maglio, V. J. in Evolution of African Mammals (eds Maglio, V. J. \& Cooke, H. B. S.) 603-619 (Harvard Univ. Press, Cambridge, MA, 1978).

2. Murdock, T. G. The Chilga Lignite Deposits. US Technical Project in Ethiopia (Mineral Investigation Memorandum no. 19, Ministry of Mines, Addis Ababa, 1944).

3. Yemane, K., Bonnefille, R. \& Faure, H. Palaeoclimatic and tectonic implications of Neogene microflora from the Northwestern Ethiopian highlands. Nature 318, 653-656 (1985).

4. Yemane, K., Robert, C. \& Bonnefille, R. Pollen and clay mineral assemblages of a late Miocene lacustrine sequence from the northwestern Ethiopian highlands. Palaeogeogr. Palaeoclimatol. Palaeoecol. 60, 123-141 (1987).

5emane, K., Taieb, M. \& Faure, H. Limnogeologic studies on an intertrappean continental deposit from the northern Ethiopian Plateau $\left(37^{\circ} 03^{\prime}\right.$ E, $12^{\circ} 25^{\prime}$ N). J. Afr. Earth Sci. 6, 91-101 (1987).

6. Spell, T. L., McDougall, I. \& Doulgeris, A. P. Cerro Toledo rhyolite, Jemez volcanic field, New Mexico ${ }^{40} \mathrm{Ar} /{ }^{39} \mathrm{Ar}$ geochronology of eruptions between two caldera-forming events. Geol. Soc. Am. Bull. 108, 1549-1566 (1996).

7. Feseha, M. Sequence Stratigraphy, Petrography, and Geochronology of the Chilga Rift Basin Sediments, Northwest Ethiopia Thesis, Univ. Texas (2001).

8. Cande, S. C. \& Kent, D. V. Revised calibration of the geomagnetic polarity timescale for the Late Cretaceous and Cenozoic. J. Geophys. Res. 100, 6093-6095 (1995).

9. Hofmann, C. et al. Timing of the Ethiopian flood basalt event and implications for plume birth and global change. Nature 389, 838-841 (1997).

10. Rochette, P. et al. Magnetostratigraphy and timing of the Oligocene Ethiopian traps. Earth Planet. Sci. Lett. 164, 497-510 (1998)

11. Ukstins, I. A. et al. Matching conjugate volcanic rifted margins: ${ }^{40} \mathrm{Ar} /{ }^{39} \mathrm{Ar}$ chronostratigraphy of pre- and syn-rift bimodal flood volcanism in Ethiopia and Yemen. Earth Planet. Sci. Lett. 198, 289-306 (2002).

12. Baker, J., Snee, L. \& Menzies, M. A brief Oligocene period of flood volcanism in Yemen: implication for the duration and rate of continental flood volcanism at the AfroArabian triple junction. Earth Planet. Sci. Lett. 138, 39-55 (1996).

13. Andrews, C. W. A Descriptive Catalogue of the Tertiary Vertebrata of the Fayum, Egypt 1-324 (British Museum of Natural History, London, 1906)

14. Tanner, L. G. in Evolution of African Mammals (eds Maglio, V. J. \& Cooke, H. B. S.) 279-283 (Harvard Univ. Press, Cambridge, Massachusetts, 1978).

15. Wight, A. W. R. in The Geology of Libya Vol. 1 (eds Salem, M. J. \& Busrewil, M. T.) 309-325 (Academic, London, 1980).

16. Pickford, M. Premiere découverte d'une faune mammalienne terrestre paléogene d'Afrique subsaharienne. Comptes Rendus l'Acad. Sci. Paris Série II 19, 1205-1209 (1986).

17. Thomas, H. et al. in Fossil Vertebrates of Arabia (eds Whybrow, P. J. \& Hill, A.) 430-442 (Yale Univ. Press, New Haven, 1999).

18. Rasmussen, D. T. \& Simons, E. L. New Oligocene hyracoids from Egypt. J. Vert. Paleontol. 8, 67-83 (1988).

19. Rasmussen, D. T. in The Evolution of Perissodactyls (eds Prothero, D. R. \& Schoch, R. M.) 57-78 (Oxford Univ. Press, Oxford, 1989).

20. Gheerbrant, E., Sudre, J. \& Cappetta, H. A Palaeocene proboscidean from Morocco. Nature 383, 68-70 (1996).
21. Gheerbrant, E. et al. A new large mammal from the Ypresian of Morocco: evidence of surprising diversity of early proboscideans. Acta Palaeontol. Pol. 47, 493-506 (2002).

22. Coppens, Y., Maglio, V. J., Madden, C. T. \& Beden, M. in Evolution of African Mammals (eds Maglio, V. J. \& Cooke, H. B. S.) 336-367 (Harvard Univ. Press, Cambridge, 1978).

23. Harris, J. M. in Evolution of African Mammals (eds Maglio, V. J. \& Cooke, H. B. S.) 315-332 (Harvard Univ. Press, Cambridge, 1978).

24. Court, N. A new species of Numidotherium (Mammalia: Proboscidea) from the Eocene of Libya and the early phylogeny of the Proboscidea. J. Vert. Paleontol. 15, 650-671 (1995).

25. Tassy, P. La Place des Mastodontes Miocènes de l'Ancien Monde dans la Phylogénie des Proboscidea (Mammalia): Hypothèses et Conjectures. PhD thesis, Mèmoires des Sciences de la Terre. Univ. Pierre et Marie Curie, Paris 85-34, 1-862 (1985).

26. Pickford, M. Cainozoic paleontological sites of Western Kenya. Münchner Geowiss. Abhandlun. 8, $1-151$ (1986).

27. Sanders, W. J. \& Miller, E. R. New proboscideans from the early Miocene of Wadi Moghara. Egypt. J. Vert. Paleontol. 22, 388-404 (2002).

28. Shoshani, J., Walter, R. C., Libsekal, Y., Abraha, M. \& Berhe, S. in Sci. Prog. Abstr. 8th Int. Theriological Congr. 128-129 (Johannesburg, 2001).

29. Boschetto, H. B., Brown, F. H. \& McDougall, I. Stratigraphy of the Lothidok Range, northern Kenya, and K/Ar ages of its Miocene primates. J. Hum. Evol. 22, 47-71 (1992).

\section{Supplementary Information accompanies the paper on www.nature.com/nature.}

Acknowledgements We thank the Authority for Research and Conservation of Cultural Heritage, the Ministry of Culture and Sports Affairs, Ethiopia, for permission to conduct our ongoing research in the Blue Nile Basin, the Director and staff of the National Museum, Addis Ababa, for their assistance with collections, and the Gondar ARCCH for logistical support. The project is funded by grants from the National Science Foundation, the National Geographic Society, the L. S. B. Leakey Foundation, and the University Research Institute of UT Austin. W.J.S. was funded in part by a Scott Turner Award from the Department of Geological Sciences of The University of Michigan. A. Asfaw, M. Birara, F. Chanic, A. Kebede and T. Selassie provided field assistance, and M. Crawford and A. Neuenschwander aided with the interpretation of the satellite imagery. B. Miljour drafted Fig. 3. We are grateful to J.-J. Jaeger for comments and insights. We thank the people of the Chilga region for their hospitality and assistance in the fieldwork.

Competing interests statement The authors declare that they have no competing financial interests.

Correspondence and requests for materials should be addressed to J.K. (jkappelman@mail.utexas.edu).

\section{Ocean currents mediate evolution in island lizards}

\section{Ryan Calsbeek ${ }^{1}$ \& Thomas B. Smith ${ }^{1,2}$}

${ }^{1}$ Center for Tropical Research, Institute of the Environment, ${ }^{2}$ Organismic Biology, Ecology and Evolution, University of California, Los Angeles, California 90065, USA

Islands are considered to be natural laboratories in which to examine evolution because of the implicit assumption that limited gene flow allows tests of evolutionary processes in isolated replicates ${ }^{1}$. Here we show that this well-accepted idea requires re-examination. Island inundation during hurricanes can have devastating effects on lizard populations in the Bahamas $^{2,3}$. After severe storms, islands may be recolonized by overwater dispersal of lizards from neighbouring islands ${ }^{3}$. High levels of gene flow may homogenize genes responsible for divergence, and are widely viewed as a constraining force on evolution ${ }^{4,5}$. Ultimately, the magnitude of gene flow determines the extent to which populations diverge from one another, and whether or not they eventually form new species ${ }^{6,7}$. We show that patterns of gene flow among island populations of Anolis lizards are best explained by prevailing ocean currents, and that over-water dispersal has evolutionary consequences. Across islands, divergence in fitness-related morphology decreases with increasing gene flow ${ }^{5}$. Results suggest that over-water dispersal after hurricanes constrains adaptive diversification in Anolis lizards, and that it may have an important but previously undocumented role in this classical example of adaptive radiation. 